\title{
DEVELOPMENT OF IMPROVED SWEETPOTATO VARIETIES IN THE PHILIPPINES: LESSONS LEARNED FROM THE CENTRAL LUZON EXPERIENCE
}

\author{
UlysSES A. CAGASAN \\ Visayas State University, Visca, Baybay City, Leyte \\ JOSE L. BACUSMO \\ Visayas State University, Visca, Baybay City, leyte \\ LILIBETH B. LARANGAN \\ Central Luzon State University, Muñoz, Nueva Ecija
}

\section{ABSTRACT}

This paper presents results of the sweetpotato varietal trials in Central Luzon, as well as the lessons learned from the Central Luzon experience.

A large number of promising genotypes was evaluated throughout the Philippines. As of the present, a total of 32 good performing sweetpotato (Sp) varieties have already been released by the National Seed Industry Council (NSIC) as recommended varieties.

Results of the regional trials conducted in Tarlac College of Agriculture (TCA) in Camiling, Tarlac revealed that the $\mathrm{Sp}$ lines recommended by NSIC were also the good performers in Central Luzon. Of these varieties, VSP. 6 was found to be widely adopted by many farmers in the area. Of the $48 \mathrm{Sp}$ clones evaluated, only five were found tolerant to viruses. These were J53-7, J60-2, Tres Colores, Tinagimtim and VSP 6.

KEY WORDS: Recommended sweetpotato varieties. Regional trials. Sweetpotato feathery mottle virus 


\section{INTRODUCTION}

Sweetpotato (Ipomoea batatas L.) continues to be one of the important crops in many places of the world. It has been used as food, feed, and raw material for several industrial products (Wheatley et al., 1995).

In the Philippines, sweetpotato is one of the most important root crops. It is cultivated by many small farmers in small patches, especially in areas no longer suitable for other crops such as upland rice and corn (Villamayor, 1991). It is used as source of cash income or as staple food among poor families, especially when rice and corn are scarce. It is also used as snack food and as one of the ingredients in the formulation of animal feeds.

To provide sweetpotato farmers, processors and consumers with wide options in terms of productivity and quality, new varieties of this crop are needed. But before a sweetpotato genotype is released as new recommended variety, it has to pass multi-location and multi-season performance trials. Thus, the National Root Crop Cooperative Testing Program (NRCCTP) was formally organized in 1982 to facilitate the development of improved root crop varieties, including sweetpotato, suited for Philippine conditions. The program has three objectives: (1) to evaluate the performance of promising sweetpotato cultivars in strategic sites across the country; (2) to analyze the dry matter, sugar, starch, and protein contents of sweetpotato cultivars evaluated in the cooperating stations; and (3) to recommend to the National Seed Industry Council $(\mathrm{NSIC})$ the release of improved sweetpotato varieties.

Implementation of the NRCCTP is spearheaded by the Philippine Root Crop Research and Training Center (PRCRTC, now PhilRootcrops) based at the then Visayas State College of Agriculture (ViSCA), now the Visayas State University (VSU) in Baybay City, Leyte. Promising genotypes developed by breeding stations such as the Philippine Root Crop Research and Training Center. (PRCRTC), University of the 
Philippine at Los Baños (UPLB), University of Southern Mindanao (USM), Northern Philippine Root Crop Research and Training Center (NPRCRTC) and Bureau of Plant Industry (BPI) are tested in cooperating research stations in the different root crop growing regions of the Philippines. At the start, the NRCCTP had 13 cooperating stations. Due to some technical problems, three of the stations were dropped, so at present, PhilRootcrops is working with only 10 cooperating stations (Table 1). One of these is the Tarlac College of Agriculture (TCA) in Central Luzon.

Table 1. The NRCCTP Cooperating Stations

\section{Name of Research Station Location}

\begin{tabular}{ll}
\hline 1. Albay Experiment Station (AES) & Tabaco, Albay (Bicol Region) \\
\hline 2. University of the Philippines at Los & College, Laguna \\
Baños (UPLB) &
\end{tabular}

3. Tarlac College of Agriculture (TCA) Camiling, Tarlac (Central Luzon)

\begin{tabular}{ll}
\hline 4. Isabela State University (ISU) & Echague, Isabela \\
\hline 5. Northern Philippine Root Crop & Benguet
\end{tabular}
Research and Training Center (NPRCRTC)

6. Bohol Experiment Station (BES) Gabi, Ubay, Bohol

7. Visayas State University (VSU) Baybay City, Leyte

8. University of the Philippines - College La Granja, La Carlota, of Agriculture Experiment Station Negros Occidental

9. Univesity of Southern Mindanao Kabacan, North Cotabato (USM)

10. Northern Mindanao Integrated Agricultural Research Center Dalwangan, Malaybalay, (NOMIARC) 
The varietal trials in Central Luzon, being part of the NRCCTP, are specifically aimed at evaluating the performance of promising sweetpotato cultivars in selected sweetpotato growing areas in Central Luzon. Results of the trials are submitted to PhilRootcrops, which takes charge in the consolidation of the results of the trials in the different cooperating stations.

This paper presents the PhilRootcrop's accomplishments and lessons learned in relation to the development of improved sweetpotato varieties that can be grown by farmers in Central Luzon and other places of the Philippines.

\section{METHODOLOGY}

\section{Development and Evaluation of New Genotypes}

The development of improved sweetpotato varieties starts with the development and evaluation of new sweetpotato genotypes by PhilRootcrops and other research institutions in the Philippines that have breeding programs. These institutions include the University of the Philippines at Los Banos (UPLB) in Laguna, Bureau of Plant Industry (BPI) in Central Office, Malate Metro, Manila, Northern Philippine Root Crop Research and Training Center (NPRCRTC) in La Trinidad, Benguet, and the University of Southern Mindanao (USM) in Kabacan, North Cotabato.

The promising genotypes generated from each breeding program are subjected to a series of tests (the single seed, single row, non-replicated and replicated trials) in each area. Genotypes that perform well in these tests are included in the regional trials. 


\section{Regional Trials}

The regional trials are established in different cooperating stations following a standard procedure set by the National Seed Industry Council Technical Working Group (NSIC-TWG) for root crops. The trials in each of the cooperating stations are managed by a study leader coming from the cooperating institution, and monitored by the NRCCTP staff from PhilRootcrops.

Each year, two trials are conducted - one for the wet season (June to December) and another for the dry season (October to May). For each trial, all cooperating stations are required to gather data on yield and reaction to insect pests and diseases, specifically scab and weevil. In addition, some of the stations also gather data on dry matter, protein, sugar, and starch contents; general acceptability; and physical characteristics (skin and flesh color, plant type) of the sweetpotato genotypes/lines evaluated.

\section{Consolidation of Regional Trial Results}

Data gathered are analyzed by the NRCCTP staff of PhilRootcrops and UPLB. The analyzed data are then evaluated by the Root Crops Technical Working Group (TWG) and the approving committee of NSIC during the annual meeting.

Genotypes that perform well in the different regional trials are recommended to NSIC by the TWG for release as new varieties. 


\section{RESULTS AND DISCUSSION}

\section{New Varieties Released as Recommended by NSIC in the Philippines}

During its 25 years of implementation (from 1982 to 2007), the NRCCTP for sweetpotato has evaluated a large number of promising sweetpotato genotypes. So far, 32 good performing varieties have been approved by NSIC as recommended sweetpotato varieties.

NSIC, however, only made national recommendations. It did not make varietal recommendations for specific regions such as Central Luzon. Based on the results of the trials conducted by TCA, the sweetpotato lines released as new varieties between 1983 to 1987 and 1997 to 2005 were also good performers in the selected testing sites in Central Luzon.

Among the lines tested in TCA and other cooperating stations and released by NSIC as recommended varieties between 1983 to 1988 , only VSP 6 has been found to be widely used by farmers in Central Luzon. This variety is known among farmers as Super Bureau due to its excellent performance in terms of yield, flavor and dry matter content. This variety surpasses the overall performance to their preferred native variety (Bureau). In 1990, attack of some viruses (known as SPFMV in Central Luzon area) wiped out their native variety. The variety was replaced by VSP 6 known to be resistant to some viruses.

\section{Performance of NSIC Recommended Sp Varieties in Tarlac}

In $1997-2005$, six of the sweetpotato entries included in the trials in Central Luzon and other cooperating stations were approved by NSIC as recommended varieties. These entries were good performers in Tarlac trials thus, they could be recommended for use among sweetpotato 
farmers in the area. However, the average yields $\left(t^{-1} a^{-1}\right)$ of these varieties in the Tarlac trials were generally lower than the average yield performance (t ha-1) of the varieties across the 10 cooperating stations (Table 2). This could be due to the unfavorable conditions of the testing sites especially during wet season.

In Central Luzon, specifically in Tarlac, sweetpotatoes are planted in ricefields after rice is harvested. During wet season, farmers use the area to grow rice. Thus, the sweetpotato trials are done in more marginal areas resulting in low yields. During dry season, ricefields, which are considered good areas, are free for sweetpotato cultivation. Thus, the average yields of the different sweetpotato entries in the Tarlac trials are higher during dry season than during wet season, except in the 2005 dry season trial which was affected by the El Niño phenomenon (Table 3).

\section{Virus Infection}

Another possible reason why the yield in Tarlac is lower than in other testing locations is virus infection. According to Palomar et al. (2000), plant viruses seem to have been gaining considerable importance for the past few years especially in areas like Tarlac and Pangasinan where sweetpotato is now commercially grown: As observed by the NCT-TCA researchers, the entries for the 1999 to 2005 trials were infected with the virus complex.

\section{Evaluation of Elite $\mathrm{Sp}$ Clones and Varieties for Resistance to SPFMV}

Following the standard procedure for evaluating entries for the NRCCTP-Sweetpotato trials, only reactions to scab and weevil were rated in the'regional trials. When SPFMV infection wiped out the sweetpotato plants in Central Luzon, no one could identify which of the NRCCTP developed varieties could tolerate virus infection and could be used by 
Table 2. Average yields (t ha-1) of the NSIC released varieties tested in Tarlac (1997 - 2005) compared with their average yield performance across 10 cooperating stations

\begin{tabular}{|l|c|c|c|}
\hline \multicolumn{1}{|c|}{ Varieties } & Year Tested & $\begin{array}{c}\text { Average Yield } \\
\text { (Tarlac) }\end{array}$ & $\begin{array}{c}\text { National } \\
\text { Average } \\
\text { (10 stations) }\end{array}$ \\
\hline $\begin{array}{l}\text { PSB Sp 22 } \\
\text { (SG94-1303) }\end{array}$ & $1998-2000$ & 3.72 & 13.72 \\
\hline $\begin{array}{l}\text { PSB Sp 23 } \\
\text { (SG95-1717) }\end{array}$ & $1998-2000$ & 8.76 & 13.78 \\
\hline $\begin{array}{l}\text { PSB Sp 24 } \\
\text { (SG95-3503) }\end{array}$ & $1999-2001$ & 4.45 & 13.00 \\
\hline $\begin{array}{l}\text { NSIC Sp 25 } \\
\text { (JK018) }\end{array}$ & $2000-2002$ & 11.76 & 11.68 \\
\hline $\begin{array}{l}\text { NSIC Sp 26 } \\
\text { (JK024) }\end{array}$ & $2001-2003$ & 13.71 & 14.62 \\
\hline $\begin{array}{l}\text { NSIC Sp 27 } \\
\text { (JK027) }\end{array}$ & $2002-2004$ & 10.31 & 13.42 \\
\hline
\end{tabular}

Table 3. Average yields (t ha- ${ }^{-1}$ ) of the different sweetpotato entries tested in Tarlac from 1998 - 2005 (wet and dry seasons)

\begin{tabular}{|c|c|c|c|}
\hline Year & Wet Season & Dry Season & Mean \\
\hline $1998-1999$ & 2.65 & 7.95 & 5.30 \\
\hline $1999-2000$ & 1.73 & 7.24 & 4.49 \\
\hline $2000-2001$ & 8.06 & 8.46 & 8.26 \\
\hline $2001-2002$ & - & 8.94 & 8.94 \\
\hline $2002-2003$ & 9.97 & 16.04 & 13.01 \\
\hline $2003-2004$ & 2.06 & 9.10 & 5.58 \\
\hline $2004-2005$ & 3.63 & 1.51 & 2.57 \\
\hline Mean & 4.68 & $\mathbf{8 . 4 6}$ & \\
\hline
\end{tabular}


the farmers to replace the varieties that had been lost. Thus, researchers from PhilRootcrops and TCA conducted two trials to identify varieties that are resistant or tolerant to SPFMV and other viruses.

Ten varieties/elite lines were included in the trials. These include: PSB Sp 20, PSB Sp 22, PSB Sp 23, PSB Sp 19, J53-7, J60-2; J76-3, Trescolores, Tinagimtim, and VSP 6 which served as check variety. Of these, five varieties/elite lines were found tolerant to viruses. These are J53-7, J60-2, Trescolores, Tinagimtim, and VSP 6 . The characteristics of these varieties are summarized in Tables 4 and 5 .

Table 4. Sweetpotato varieties and elite lines found tolerant to sweetpotato feathery mottle virus (SPFMV) and other viruses

\begin{tabular}{|c|c|c|c|c|c|}
\hline $\begin{array}{c}\text { Varieties/ } \\
\text { Lines }\end{array}$ & Survival & $\begin{array}{c}\% \text { Virus } \\
\text { infection }\end{array}$ & \multicolumn{2}{|c|}{ Root Yield (t ha-1) } & Herbage Yield \\
(t ha-1)
\end{tabular}


Table 5. Characteristics of $\mathrm{Sp}$ varieties and elite lines found tolerant to SPFMV and other viruses

\begin{tabular}{|c|c|c|c|c|}
\hline $\begin{array}{c}\text { Varieties/ } \\
\text { Lines }\end{array}$ & $\begin{array}{c}\text { Skin } \\
\text { Color }\end{array}$ & $\begin{array}{c}\text { Flesh } \\
\text { Color }\end{array}$ & $\begin{array}{c}\% \text { Dry } \\
\text { Matter }\end{array}$ & $\begin{array}{c}\text { General } \\
\text { Acceptability }\end{array}$ \\
\hline J53-7 (2 trials) & $\begin{array}{c}\text { Light } \\
\text { Red }\end{array}$ & Purple & 30.3 & 7.45 \\
\hline J60-2 (2 trials) & $\begin{array}{c}\text { Light } \\
\text { Orange }\end{array}$ & $\begin{array}{c}\text { Light } \\
\text { Yellow }\end{array}$ & 25.8 & 7.35 \\
\hline Trescolores (2 trials) & $\begin{array}{c}\text { Light } \\
\text { Red }\end{array}$ & $\begin{array}{c}\text { Light } \\
\text { Orange }\end{array}$ & 29.7 & 7.35 \\
\hline $\begin{array}{c}\text { Tinagimtim (1 trial) } \\
\text { Red }\end{array}$ & Purple & 30.0 & 6.40 \\
\hline $\begin{array}{c}\text { VSP 6 (check variety } \\
\text { in trials) }\end{array}$ & Purple & White & 32.9 & 7.58 \\
\hline
\end{tabular}

\section{LESSONS LEARNED}

1. In the NRCCTP, development of improved sweetpotato varieties is guided only by the breeders' criteria. The same criteria (i.e., yield; resistance to insect pests and diseases specifically weevil and scab; and dry matter, starch, sugar and protein contents) are used in all location trials. But there is still a question on what really are the criteria used by farmers from different places in choosing sweetpotato varieties to use? As observed, VSP 6 was highly adopted by farmers because it had similar characteristics with that of their preferred variety named Bureau, which was wiped out due to virus infection. In fact, they named VSP 6 as Super Bureau because it yielded higher than Bureau. Farmers in other area may also have their own bases of choosing varieties to 
use. Therefore, in addition to the breeders' criteria, activities to allow selection by farmers using their own criteria should also be considered in the development of improved genotypes, and in the evaluation of the sweetpotato entries at the regional trials.

2. In screening for pest resistance, only scab and weevil were considered. However, the Central Luzon case has shown that aside from weevil and scab, there could be other important sweetpotato pests and diseases in particular regions or places that should be considered in the varietal trials - like the SPFMV in Central Luzon. Thus, screening of varieties that are resistant or tolerant to the dominant pests and diseases in the area should be an additional data that should be gathered in the sweetpotato varietal trials in regions with specific pest and diseases concerns.

The study leader of the NCT in TCA has already started conducting a research study on the screening of sweetpotato varieties for resistance to SPFMV. During the wet and dry season croppings in 2000 , she conducted a varietal screening in Tarlac using $48 \mathrm{CIP}$ clones. Most of the CIP clones evaluated expressed symptoms of virus infection such as vein clearing, yellowing, curling of the leaves, purple ring spots and kulot (combination of any of the above mentioned symptoms). There were 15 clones observed to be free of virus infection, but these clones did not have good agronomic performance. The storage roots produced by the rest of the clones evaluated were also non-marketable even when harvested at 120 DAP. Further study should be conducted to identify good performing varieties that can tolerate virus infection. 
3. The NSIC made only national varietal recommendations, not varietal recommendations for specific regions such as Central Luzon. Although results of the trials conducted in the region showed that the sweetpotato lines released as new varieties were also good performers in the selected testing sites in Central Luzon, the Central Luzon experience showed that a particular region may have some problems (such as prevalence of some pests) that are supposed to be considered in the development of sweetpotato varieties that would be appropriate in the area. Thus, it may be better if regional varietal recommendations should also be made.

4. After almost two decades of conducting varietal trials in Central Luzon, there is no hard data yet that would show which of the recommended sweetpotato varieties are acceptable and have been used by farmers in the area. Also, there is no data yet on the performance of these varieties in the farmers' fields. So far, only the wide adoption of VSP 6 by farmers have been reported. How about the other varieties? Were these used by farmers also? To identify the best varieties for the Central Luzon area, there may be a need to conduct farmers' acceptability trials in Central Luzon and in other testing locations.

The study leader of the NCT in TCA has started addressing this concern through her ongoing research project entitled Collection, Micropropagation and Evaluation of PSB/NSIC approved and other local varieties. The project aims to evaluate the agronomic performance of these varieties in different agroecological zones and to determine the use of each variety (for food and feed). This is also to make these varieties available to farmers. 


\section{LITERATURE CITED}

PALOMAR, M.K., E.B. BARSALOTE and H.S.V. COLIS. 2000. Distribution, transmission and disease characterization of sweetpotato feathery mottle virus. Annals of Tropical Research, 22(1\&2): 16-30.

VILLAMAYOR, FG. 1991. Status and production potential of cassava and sweetpotato in Leyte. In: Librero, A.R. and M.K. Palomar (eds). Root Crops in the Philippines: Status, Potential and Policy Issues. Los Baños, Laguna, Philippines: PCARRD.

WHEATLEY, C., G.J. SCOTT, R. BEST AND S. WIERSEMA. 1995. Adding Value to Root and Tuber Crops: A Manual on Product Development. Colombia:CIAT. 167 pp.

\section{ACKNOWLEDGMENT}

The authors gratefully acknowledged the financial support of PhilRootcrops-VSU in the implementation of this project, and the study leaders in the cooperating stations throughout the Philippines who supervised the project implementation. 